\title{
Michel Vergé-Franceschi, Pozzo di Borgo. L'ennemi juré de Napoléon. Paris: Editions Payot et Rivages, 2016, 412 p.
}

\author{
Е.В. Линькова (рецензент) \\ Российский университет дружбы народов \\ 117198, Россия, Москва, ул. Миклухо-Маклая, 6 \\ e.v.linkova@yandex.ru
}

Мировоззрение и деятельность российского дипломата корсиканского происхождения Шарля Андре Поццо ди Борго привлекают неослабевающее внимание российских и зарубежных ученых, о чем свидетельствуют как научные труды, так и ежегодные конференции ${ }^{1}$, центральной темой которых становится фигура этого талантливого государственного деятеля. Подобный интерес вызван целым рядом факторов. Поццо ди Борго стал своеобразным символом эпохи, непосредственно связанной с одним из переломных моментов российской истории - периодом наполеоновских войн. Весьма примечательным является и тот факт, что в первой половине XIX в. в России фамилия корсиканца стала практически нарицательной и ассоциировалась с профессией дипломата. «...У нашего провинциала все русские послы и посланники Поццо ди Борги...»², - писал П.А. Вяземский.

Кроме того, корсиканский дипломат - это яркий представитель французской эмиграции в России конца XVIII - начала XIX в. - этого уникального феномена, оказавшего существенное влияние на эволюцию российской общественно-политической мысли и на развитие внешнеполитического курса страны. Необходимо отметить и весьма важную роль, которую сыграл Поццо ди Борго в урегулировании послевоенного положения, в определении роли и миссии России на международной арене после 1813-1815 гг. Участие русской армии в антинаполеоновских коалициях,

${ }^{1}$ В качестве примера можно привести следующие конференции: Pozzo di Borgo (1764-1842), Colloque international. Alata, 2017; (Autour de Charles-André Pozzo di Borgo (1764-1842). Cousin de Napoléon et ambassadeur de Russieen France. Actes du colloquetenu à Alata, son village natal, sur les hauteursd Ajaccio les 26 et 27 mai 2017 (Ajaccio, 2018); Premières journées d'Histoire diplomatique d'Alata. Autour de l'ambassadeur Charles-André Pozzo di Borgo. Colloque international (Alata, 2018).

2 Вяземский П.А. Старая записная книжка. 1813-1877. М.: Захаров, 2003. С. 652. 
Тильзит, Отечественная война 1812 г., становление Венской системы, Европа эпохи конгрессов, - все эти события и явления становятся знаковыми и красной нитью проходят через жизнь французского дипломата, определяя его мировоззрение, способствуя новым виткам карьеры.

Именно поэтому изучение взглядов и деятельности Поццо ди Борго это, в первую очередь, попытка осмысления целой эпохи, ее особенностей, а также тех великих личностей, которые оказывали влияние на ход развития государств и народов. Вот почему, приступая к исследованию личности Шарля Андре Поццо ди Борго, французский историк, профессор Университета Тура, Мишель Верже-Франчески, в первую очередь обращается к историческому контексту, к тем условиям, в которых сложились идейные установки французского дипломата. История становления мировоззрения Поццо ди Борго - это история Европы, Франции, России, Корсики. Та идейная эволюция, которая была свойственна для поколения, оказавшегося в самом центре революционных событий конца XVIII - начала XIX в., те политические потрясения, войны, которые наполняли особым содержанием жизнь и помыслы целой генерации людей, - все это нашло отражение в работе французского историка. Данный период являл собой сложный этап в процессе становления и трансформации самосознания европейских народов, он отмечен духовным и «национальным брожением» . И в этом смысле монография М. Верже-Франчески - это первая в своем роде попытка на основе исследования мировоззрения и деятельности отдельно взятого государственного деятеля - Шарля Андре Поццо ди Борго - реконструировать сложный и многомерный образ эпохи, которая остается притягательной для современных исследователей, находящих все новые грани и лакуны в ее изучении.

Как во Франции, так и в России, история наполеоновских войн является актуальной научной проблемой в рамках изучения истории международных отношений, а также внутриполического, культурного, духовного развития отдельных государств Европы. Обращение в монографии к личности дипломата, описание его жизненного пути, карьеры, взглядов тесно связано с попыткой осмысления сущности идейной борьбы между двумя корсиканцами - Поццо ди Борго и Наполеоном. Автор показывает, что в основе данного противостояния лежали не только политические разногласия, но и личностные факторы, духовное размежевание.

Книга М. Верже-Франчески - это фундаментальный труд, основанный на документах, хранящихся в архивах Российской Федерации и Франции, а также в личных коллекциях (например, семьи Поццо ди Борго). Более того, в мо-

\footnotetext{
${ }^{3}$ Пыпин А.Н. Панславизм в прошлом и настоящем. М.: Граница, 2002. С. 3.
} 
нографии дается обширный историографичекий обзор, посвященный не только деятельности Поццо ди Борго, но и в целом наполеоновской эпохе.

Репрезентативная источниковая база, критическое отношение к историографической традиции - все это позволило французскому историку представить свой взгляд на личность и мировоззрение Поццо ди Борго, показать влияние эпохи на судьбу французских эмигрантов, во всей полноте продемонстрировать их убеждения и ценности.

М. Верже-Франчески строит свое повествование на детальном и последовательном изложении ключевых событий, произошедших в жизни Поццо ди Борго, раскрывает взаимосвязь его мировоззрения и деятельности с событиями эпохи. Ключевым аспектом монографии является изучение истории отдельного региона Франции - Корсики, откуда родом был и Шарль Поццо ди Борго, и его политический оппонент - император Наполеон Бонапарт. Корсиканская тема не утратила свою важность и остроту и для современной Франции, а в конце XVIII - начале XIX в. представляла особую актуальность. Безусловно, эмиграция из данного региона едва ли может быть выделена в особое направление, так как корсиканцы в России были весьма малочисленны и не обособлены от основной массы французов. Однако в силу того, что национальная идентичность корсиканцев вызывала массу дискуссий и споров как во Франции рубежа XVIII-XIX в., так и в современном французском обществе, а многие корсиканцы до сих пор продолжают позиционировать себя весьма независимо, сама постановка проблемы о роли истории, культуры и традиций Корсики в формировании мировоззрения Поццо ди Борго не вызывает сомнений. Известно, что сам дипломат, отвечая на вопрос о том, какое «...корсиканцы имеют сердце французское или итальянское?», отвечал: «корсиканское» ${ }^{4}$.

И Поццо ди Борго, и Наполеон происходили из корсиканского дворянства и были яркими представителями этой «мятежной» части Франции. Деятельность идейных и политических лидеров Корсики, таких как, например, генерал Паскаль Паоли, также весьма детально представлена в монографии французского историка. Таким образом, перед читателем открывается многомерная картина французской действительности и внутриполитической жизни конца XVIII - начала XIX столетия, в которой тесным образом переплетались революционная борьба, национальный вопрос, амбиции европейских держав, а также личные качества и устремления отдельных исторических личностей.

${ }^{4}$ Michel Vergé-Franceschi, Pozzo di Borgo, L'ennemi juré de Napoléon (Paris: Editions Payot et Rivages, 2016), 11. 
Монография французского ученого представляет собой оригинальное произведение, которое призвано обогатить представления читателей об истории России и Европы первой четверти XIX столетия. Более того, благодаря исследованию деятельности Поццо ди Борго автор показывает и весь масштаб личности его идейного противника - Наполеона Бонапарта. Примечательно, что М. Верже-Франчески начинает свое повествование о судьбе корсиканского дипломата словами французского императора о том, что «Поццо ди Борго посоветовал Александру I идти на Париж, что... peшило судьбы Франции...»

Можно отметить, что исследование мировоззрения, жизненных перипетий, карьеры Поццо ди Борго дает французскому историку возможность с новой стороны взглянуть на сущность наполеоновской эпохи, проследить, насколько важной может быть роль отдельно взятой личности в истории. Пример идейной борьбы Шарля Андре Поццо ди Борго и Наполеона Бонапарта - это пример той масштабной дискуссии по вопросам будущего народов Европы, которая развернулась вследствие революционных потрясений и войн конца XVIII - начала XIX в.

В заключение необходимо отметить особую значимость данной монографии для российского научного сообщества. Работа М. Верже-Франчески расширяет рамки исследований в сфере анализа и реконструкции российско-французских отношений XIX в., знакомит с обширной базой опубликованных и архивных материалов, приглашает к дальнейшему научному поиску в области изучения наполеоновской эпохи, сыгравшей ключевую роль не только в судьбах Франции и Европы в целом, но и России.

\title{
Michel Vergé-Franceschi, Pozzo di Borgo. L'ennemi juré de Napoléon. Paris: Editions Payot et Rivages, 2016, 412 p.
}

\author{
Elena V. Linkova (reviewer) \\ RUDN University \\ 6 Miklukho-Maklaya St., Moscow, 117198, Russia \\ e.v.linkova@yandex.ru
}

${ }^{5}$ Michel Vergé-Franceschi, Pozzo di Borgo, L'ennemi juré de Napoléon (Paris: Editions Payot et Rivages, 2016), 9. 